\title{
Erkek öğrenci hemşirelerin halk sağlığı stajında yaşadıkları endişe ve deneyimler: Şanlıurfa örneği
}

\author{
Selma Kahramana
}

\section{Özet}

Amaç: Araştırmanın amacı ilk defa halk sağlığı stajına çıkacak olan erkek öğrenci hemşirelerin alanda yaşadığı endişe ve deneyimleri tanımlamaktır. Yöntem: Harran Üniversitesi Sağlık Yüksekokulu Halk Sağlığı stajı alan 27 erkek öğrenci hemşire ile yürütülen tanımlayıcı bir çalışmadır. Veriler yarı yapılandırılmış bir görüşme formuyla toplanmıştır. Bulgular: Erkek öğrencilerin tümü ev ziyaretlerine kız arkadaşlarıyla birlikte gitmişlerdir. Ev ziyaretlerinde doğrudan iletişim kuramadıklarını, stajın bu haliyle çok verimli olmadığını ifade etmişlerdir. Sonuç: Halk sağlığı uygulamalarında erkek öğrenciler dirençle karşılaşmış ve bu yüzden hem topluma hem da kendisine faydalı olmadığı ve öğrenmenin azaldığı, değişimin yavaş olduğu belirlenmiştir.

Anahtar Kelimeler: Erkek hemşire, hemşirelik, halk sağlığı.

\section{Concerns and experiences of male nursing students in public health clerkships: An example from Şanlıurfa}

\begin{abstract}
Objective: To determine the experiences and related concerns of male nursing students participating in a Public Health clerkship for the first time. Methods: Data were collected using semi - structured interviews with from 27 nursing students. Results: All male students said that they went on house visits with female student partners. They had difficulty getting direct communication with people during those visits and reported that the experience was neither useful nor satisfying. Conclusions: Male nursing students experienced a resistance from society during their public health field practice. They indicated this as a problem that affects their learning.
\end{abstract}

Key Words: Male nurse, field study, public health.

a Harran Üniversitesi Sağlık Yüksekokulu Halk Sağlığı̆ Hemşireliği, Şanlıurfa

Sorumlu Yazar: Selma Kahraman, Harran Üniversitesi Sağlık Yüksekokulu Halk Sağlığı Hemşireliği, 63050, İpekyol, Şanlıurfa. Tlf: 0414-3513060; Faks: 0414-3512700; E mail: selmadinc@mynet.com

Geliş tarihi: 11.03.2013, Kabul tarihi: 02.08.2013

Turk J Public Health 2013;11(3) 
Giriş

Toplumun sağlı düzeyinin korunmasında ve yükseltilmesinde halk sağlığı uygulamalarının yeri çok önemlidir. Tedavi hizmetlerinin artan maliyetleri, hastalıkların yarattığı işgücü kaybı hastalıklardan korunma hizmetlerini daha önemli kılmaktadır. Özellikle halk sağlığı hemşireliği toplum bireylerine ulaşarak kendilerine hastalık olup olmadığı, var olan sağlık tehlikelerinden nasıl korunacakları ve sağlık durumun geliştirilmesi amacıyla hizmet vermektedir. ${ }^{1-3}$

Halk sağlığı hemşireliği bu amaçlara ulaşabilmek için toplumdaki birey ve aileleri yaşadıkları ortamda izler, onlara ilişkin veri toplar, problemleri saptar, bu problemleri öncelik sırasına koyarak her bir probleme uygun amaç geliştirir. Günümüzde hemşirelik; profesyonelliğe ve kişilerarası ilişkilere dayanan dinamik bir süreç oluşuyla, gelişmiş ülkelerde her iki cinsiyet tarafindan da uygulanabilmektedir. Bir mesleğin gerektiği şekilde yürütülebilmesi, hem bu meslekte çalışanların verdiği hizmetten doyum bulmasını, hem de hizmet alan bireyin yarar görmesini ve hoşnut olmasını sağlar. Yalnız kadınlara özgü bir meslek olmanın bazı sorunlara neden olduğu hem çalışma alanındaki hemşireler, hem de öğrenci hemşireler tarafından zaman zaman yakınmalara neden olmakta, erkek meslektaşları ile bu sorunları paylaşmanın ve üstesinden gelebilmenin daha kolay olabileceği fikrini ileri sürmektedirler. ${ }^{3} \mathrm{Bu}$ süreçte Türkiye'de hemşirelik mesleğine erkeklerin katılmasıyla hemşirelik mesleğinin profesyonel şekilde gelişimi sağlamada önemli bir adım atılmıştır. Hemşirelikte erkek sayısının arttırılmak istenmesinde, hemşireliğin daha iyi bir statü kazanması, cinsiyette denge sağlanması ve erkeklerin bu mesleğe olan endişelerini azaltması yatmaktadır.4 Ancak değişim süreci her zaman sıkıntılı ve ilkleri yaşayanlar açısından stresli olabilmektedir. . $^{1-3,5,6}$
Sosyal yapı, hemşirenin tutumlarını, hemşirelik uygulamasını ve toplumun hemşireliğe karşı tutumlarını biçimlendirir. Erkeklerin en fazla sosyal yapı ile bütünlük içinde olan bölüm halk sağlığıdır. $\mathrm{Bu}$ nedenle erkek öğrenci hemşirelerin hem kendisinde hem de toplumda yaşadığ sıkıntılar ve çatışmaların en çok yaşandığı yer yine halk sağlığında olmuştur. ${ }^{3-8} \mathrm{Bu}$ çerçevede bu çalışma erkek hemşire öğrencilerin halk sağlığı uygulamalarında yaşadığı çatışmaları ve baş etme mekanizmalarını belirlemek amacıyla yapılmıștır.

\section{Gereç ve Yöntem}

Araştırma Harran Üniversitesi Sağlık Yüksekokulu 4. sınıf halk sağlı̆̆ı hemşireliği dersi alan tüm erkek öğrencilerin $(n=27)$ deneyimleri yansıtmaktadır. Öğrencilere araștırmanın amacı anlatılarak araştırmaya katılması için onam alınmıştır. Araştırmanın verileri yarı yapılandırılmış bir görüşme formuyla toplanmıştır. Araștırmacı tarafından halk sağlığı stajının başında ve sonunda olmak üzere erkek öğrencilerle iki defa yüz yüze görüşme yapılmıştır. Yarı yapılandırılmış görüşme formu halk sağlığı stajı amaçları doğrultusunda erkek olarak ilk ev ziyaretinde yaşadığı sıkıntılar, sonraki ziyarette yaşanan durumlar ve son öneriler olmak üzere sorulardan oluşmaktadır. Bir görüşme ortalama 10 ile 15 dakika sürmüştür. Araștırmanın değerlendirmesi öğrencilerin halk sağlığı stajının başında ve sonundaki ifadelerin değişimi ile değerlendirilmiştir.

\section{Bulgular}

Erkek hemşire öğrenciler çoğunlukla 22-27 yaş grubundadır. Öğrencilerin \%48,1'i Şanlıurfa merkez, \%44,4'ü Diyarbakır ve \%7,4'ü Mardin'li olduğu saptanmıştır. Öğrencilerin çoğunluğu hemşirelik mesleğine gelme nedeni olarak $\% 59,4$ hemşirelik mesleğinin maddi imkanların daha iyi olması, iş bulma

Turk J Public Health 2013;11(3) 
imkânının daha fazla olması, geri kalanlar ise ailesi istedikleri ya da puanı tuttuğu için seçtiklerini ifade etmiştir.

Erkek öğrenci hemşirelerin \%80,6'sı 'halk sağlığı uygulamalarında erkek hemşire olmalı mıdır?' sorusuna ilk olarak aşağıdaki ifadeleri kullanmıştır:

"Erkek hemşire olmalıdır ama kadın hastaların olmadığı yerde daha çok kadın doğum servislerin dışında olmalıdır. Halk sağlığında da daha çok kadınla muhatap olunduğu için erkek hemşire olmamalıdır."

"Halk sağlığında erkek hemşire olmalıdır. Cü̈kü kız arkadaşlarımızın güvenliği sorun olabilir. Bu yüzden bizler onu koruyucu olarak çıkabiliriz. Mahrem konularda kız hemșireler kızlarla konuşurken, erkek hemşireler erkeklerle konuşma durumda olmalıdır. Ancak ev ziyaretlerinde genellikle erkek hemşireler yer almamalı onlar dışarı işlerde yani iş sağlığında ya da okul sağlığında olmalıdır."

"Erkek hemşireler Şanlıurfa gibi kapalı yerlerde olmamalıdır. Çünkü bu tür yerlerde kadına ve erkeğe çok fazla laf gelir. Ev ziyaretlerinde erkek hemşirenin ailenin kabul etmesi çok zordur. Evde kadının olması erkek hemşireyi eve sokması yanlış anlaşılır. Ya da kocası kızabilir. Ben de yaşadığım ev ziyaretlerinde çok zorlandım. Kız arkadaşım olmadan eve giremedim. Bu yüzden erkekler halk sağlığında olmamalıdır."

Araştırmanın sonunda iki öğrencinin ifadesi aşağıdaki gibi değişime uğramıştır:

"Halk sağlığı stajına başlamadan önce kaygılarım çok fazla vardı. Hep reddedilme ve erkek olduğumdan dolayı insanların bana derdini söylemeyeceğini düşündüm. Ancak uygulamadan sonra kendi önyargılarımı yendiğimi ve ben bunu aşarsan insanların da o gözle baktığını gördüm. Uygulama ne olursa olsun erkek kadın fark etmeksizin herkes yapmalıdır. Halk buna alışmalıdır."

"Erkek hemșireler bence kendi önyargılarından dolayı bu kadar sıkıntı yaşadılar. Oysa erkek hemşirelerde toplum tarafindan kabul görmesi için önce bizim aşmamı cinsiyetimizi değil mesleğimizi ön plana çıkartmamız gerekir. Şanlıurfa bölgesi de buna alışmalı. Bence benim arkadaşların kendi değerlerine uymadiğı için bu kadar karşı çıktılar. Oysa ben gittiğim ev ziyaretlerinde erkek diye bir sıkıntı yaşatmadılar. Uygulamalarımı yaptım. Etkili oldu. Erkek hemşire her yerde olmalıdır."

Erkek öğrencilerin ilk ev ziyaretinde yaşadıkları deneyimleri sorulduğunda öğrencilerin hepsi ilk ev ziyaretinde kız arkadaşı ile birlikte gittiği, kapı açıldığı zaman kız arkadaşının onun yerine konuştuğunu belirtmişlerdir. Kız arkadașı bundan sonraki ziyaretleri erkek arkadaşının yapacağını söyleyince ailelerin \%60'ı kabul etmemiș, \%40'ı ise kız arkadașı ile gelmek koşulu ile ev ziyaretini kabul etmiștir. Bu durumu iki öğrenci aşağıdaki gibi ifade etmiştir:

"Ev ziyaretini genellikle kiz arkadaşımla beraber yaptım. Evde kadın olduğu için kız arkadaşıma soruyor o cevapliyordu. O olmadiğı zamanlarda eve giremiyordum. $B u$ yüzden evimi hiç sahiplenemedim. Bu yüzden zorlandım ve etkili olamadım."

"Ev ziyaretlerinde en çok zorlandığım alanlar kadına fiziksel muayene yaparken olmuştur. Kadın çekindiği için ben de çekindiğim için vital bulguların dışında çok fazla muayene edemedim. Eğitimde uygulamalarında mahrem konulara giremedim. Sanki bu aile benim ailem değil de kız arkadaşımın ailesi ben sanki kız arkadaşıma yardım ediyormuşum gibi"

"Kızların bizimle beraber gelmesi onların iș yükünü çok artırdı. Bu yüzden onların sanki iki ailesi bizim de hiç ailemiz yokmuş gibi oldu. Kız arkadaşım başka işi olduğu zaman bir kere aileme tek başıma gittim. Beni içeri almadı. Bu yüzden kendimi rencide olmuşum gibi hissettim."

Halk sağlığının stajının sonunda erkek öğrenciler ev ziyaretlerinden dolayı çok üzüldüklerini, bir şeye yaramadığını ve

Turk J Public Health 2013;11(3) 
yorgunluğun çok fazla olduğunu ifade etmişlerdir. $\mathrm{Bu}$ yüzden Şanlıurfa gibi geleneksel yaşam biçiminin yaşandığ bölgelerde halk sağlı̆̆ı stajında bir kız ve bir erkeğin aynı aileyi alması, ya da erkeklerin ev ziyaretlerinden sorumlu tutulmaması önerilmiştir.

\section{Tartışma}

Erkek hemşire öğrencilerin hemen hepsinin güneydoğu kültüründe olduğu söylenebilir. Halk sağlığı stajı hakkında kullandığı ifadelere göre halk sağlı̆̆ uygulamalarında genellikle kız hemșire öğrencilerin yer alması ile daha kolay olabileceği ve zorlanmanın yașanmayacağını ifade etmektedir. Erkeklerin sadece koruyucu görevinin dişında aktif olamayacağı ayrı bir noktadır. $\mathrm{Bu}$ öğrencilerin stajdan sonra düşüncelerinde değişmenin çok az olduğu erkek hemşirenin ev ziyaretlerinde olmaması gerektiği tekrar söylemiştir.

$\mathrm{Bu}$ sonuçlar ışığında erkek öğrencilerin geleneksel bakış altında hemşirelik mesleğini değerlendirdiği, bu yüzden kadına yönelik yapılan hemşirelik uygulamalarını sınırlandırdığı söylenebilir. $\mathrm{Bu}$ bakışın değişmesi zaman alacaktır. Öğrencilere göre hastaların kendileri ile ilgili düşüncelerine bakıldığında; yarısından biraz fazlası sorun yasamadıklarını, yaklaşık $1 / 4$ 'ü hemşire olmalarını yadırgadıklarını, $1 / 10$ 'u hastaların kendilerine hitap sekli seçmekte zorlandıklarını dile getirmiştir. Taşçı'nın kadın doğum servislerinde yatan hastaların erkek hemşireler hakkındaki düşünceleri baslıklı çalışmasında ise hastaların, \%71'i erkek hemșireden bakım almak istemediğini ve $\% 65,1$ 'i erkek hemşirenin kendisine bakım vermesinden rahatsız olacağını belirtmiştir. ${ }^{5}$ Oktay'ın çalışmasında ise hastaların kendilerine hangi cinsten hemşirenin bakmasını istedikleri incelenmiş, hastaların çoğunluğunun kadın hemșirelerden bakım almak istedikleri görülmüştür. ${ }^{9}$ Ayrıca Taşçı'nın çalışmasında hastaların, \%64'ü
Türkiye'de hastanelerde çalışan erkek hemşire olup olmadığını bilmediğini, \%43'ü erkek hemşirelerin iyi bakım verebileceğini ve hemşirelik mesleği ile ilgili olumsuz/yanlış düşünceleri değiștireceğini belirtmiștir. ${ }^{5}$ Özbasaran ve Taspınar'ın çalışmasında, çalışan hemşirelerin \%17'si erkek hemşirelerin toplumun bakış açısını değiştireceğini belirtmiştir. ${ }^{10}$ Karadakovan'ın çalışmasında da, öğrencilerin \%64,6'sının erkek hemşirelerin mesleğin toplumdaki statüsünü arttıracağını düşündükleri ifade edilmektedir. ${ }^{6}$

\section{Sonuç ve öneriler}

$\mathrm{Bu}$ çalışmada halk sağlığ uygulamalarında erkek hemşire öğrencilerin çoğu dirençlerle başladığı ve bu yüzden hem topluma hem da kendisine faydalı olmadığı ve öğrenmenin azaldığı, değişimin yavaş olduğu belirlenmiștir. $\mathrm{Bu}$ sonuç ışı̆̆ında:

-YÖK, Sağlık Bakanlığı ve Hemşirelik dernekleri medya ile işbirliği içerisine girerek hemşirelik mesleğinde cinsiyet ayrımı olmadığını anlatan programlar yapılması,

-Hemşirelik ile ilgili eğitimlere, kongre ve sempozyumlara yurtdışında çalışan erkek hemşirelerin davet edilerek rol modeli olmalarının sağlanması,

-Sahada çalışan erkek hemşire sayısının artırılması gibi öneriler getirebilir.

\section{Teşekkür}

$\mathrm{Bu}$ araştırma için tüm içtenliğiyle deneyimleri aktaran 2012 halk sağlığı dersi alan erkek öğrencilere teșekkür ederim.

\section{Kaynaklar}

1. Öztek Z. Kubilay G. Toplum Sağlığı Hemşireliği. Palme Yayıncılık. Ankara. 2005;2-9. 
2. Bayık A, Erefe İ, Özsoy SA, Uysal A, Özer M, Ergül Ş. Kadın Mesleği Olarak Hemşireliğin Gelişimi. Hemşirelik Forumu 2002;5(6):16-25.

3. İnanç $N$, Üstünöz A. Kadın, Güç Ve Hemşirelik. Hemşirelik Forumu 1998;1(2):5-70.

4. Bozkır G, Tasçı N, Arsak A. Genel Lise Son Sınıf ve Sağlık Yüksekokulu'ndaki Erkek Öğrencilerin Hemşireliğe Bakışı, Bilim Eğitim Ve Düşünce Dergisi 2008;8(1):1-16.

5. Tasçı KD. Kadın Doğum Servisinde Yatan Hastaların Erkek Hemşireler Hakkındaki Düşünceleri. Atatürk Üniversitesi Dergisi 2007;10(2):12-19.

6. Karadakovan A. Ege Üniversitesi Hemşirelik Yüksekokulu Öğrencilerinin Mesleğin Toplumdaki Statüsü Ve Hemşireliğe Erkek Öğrenci Alınmasına İlişkin Görüşleri, III. Hemşirelik Eğitimi Sempozyumu, İstanbul. 1993;376-373.

7. Ökdem Ş, Abbasoğlu A, Doğan N. Hemşirelik Tarihi, Eğitimi Ve Gelişimi, Ankara Üniversitesi Dikiş Hizmetleri Meslek Yüksekokulu Yıllığı 2000;1(1):511.

8. Yavuz M, Dramalı A. Erkek Öğrencileri İçeren Hemşirelik Eğitimi, IV. Ulusal Hemşirelik Sempozyumu, Kibrıs. 1997;234-237.

9. Oktay S. "Hastalar Kendine Bakım Verenlerin Hangi Cinsten Olmasını İster?" Hemşirelik Bülteni 1989;3(14):23-30.

10. Özbasaran F, Taşpınar A. Hemşireler Mesleklerine Erkek Üye Alınmasını istiyorlar mi? Ege Üniversitesi Hemşirelik Yüksekokulu Dergisi 1998;14(3):271-281. 